\title{
Mutations of Phage P22 affecting Phage DNA Synthesis and Lysogenization
}

\author{
Myron Levine and Carol Schott \\ Department of Human Genetics \\ The University of Michigan, Ann Arbor, Mich. 48104, U.S.A. \\ (Received 1 April 1971, and in revised form 19 July 1971)
}

\begin{abstract}
Two temperature-sensitive mutants of phage P22, $t s 18.1$ and $t s 12.1$, are described which have recessive DNA-negative phenotypes. At high temperature they fail to synthesize phage DNA. In mixed infection with the two mutants or either mutant and wild-type phage, DNA synthesis and phage production are normal. In addition, under non-permissive conditions, these mutants fail to lysogenize and show dominant integration-negative phenotypes. They do not complement for lysogenization in mixed infection and each of these mutants interferes with lysogenization by wild type. At low temperature each mutant shows normal phage production and normal frequencies of lysogenization. These mutant lysogens are stable at high temperature. The data suggest the requirement for common functions for genome replication and prophage integration. The mutations are closely linked and map just to the right of the $c$ region in map positions analogous to genes $O$ and $P$ of phage $\lambda$.
\end{abstract}

\section{Introduction}

In the course of selection and characterization of temperature-sensitive mutants of phage P22, two mutants have been isolated the gene products of which must act early in the latent period for normal phage production. At high temperature, these mutants have been characterized as being negative for phage DNA synthesis and in addition are not able to establish the lysogenic condition.

\section{Materials and Methods}

(a) Bacteriophage strains

Wild-type phage P22, the plaque-morphology mutants, $m_{3}$ and $h_{21}$, and the clear mutants, $c_{1}$ and $c_{2}$, have been previously described (Levine, 1957; Levine \& Curtiss, 1961). The clear mutations are closely linked and interfere with the ability to lysogenize.

The three temperature-sensitive $(t s)$ mutants, $t s 5.1, t s 12.1$ and $t s 18.1$, used in this report, were isolated from wild-type phage P22 mutagenized with 1-methyl-3-nitro-1-nitrosoguanidine. These mutants were selected to produce plaques at $25^{\circ} \mathrm{C}$ and to form no plaques at $37^{\circ} \mathrm{C}$. On infection of sensitive cells in liquid culture, each produces $10^{-4}$ to $10^{-5}$ plaque-forming units at $37^{\circ} \mathrm{C}$ as compared to $25^{\circ} \mathrm{C}$.

\section{(b) Bacterial strains}

Wild-type Salmonella typhimurium LT2, strain 18, was used as the sensitive host in all infections. A galactose-negative mutant was used as indicator bacteria.

(c) Media

L broth (Levine, 1957), M9-CAA medium (Smith \& Levine, 1964), EMB galactose agar (Levine, 1957) and indicator agar (Levine \& Curtiss, 1961) have been described previously. 


\section{(d) Determination of the rate of DNA synthesis}

The rate of DNA synthesis was estimated by measuring the incorporation of $\left[{ }^{3} \mathrm{H}\right]$ thymidine into acid-insoluble material in uninfected or infected cells during a oneminute pulse. The method used is the same as that reported by Smith \& Levine (1964). Samples of $0.5 \mathrm{ml}$. of bacterial suspension in M9-CAA medium were incubated for $1 \mathrm{~min}$ with $0.05 \mathrm{ml}$. of $\left[{ }^{3} \mathrm{H}\right.$ ] thymidine (spec. act. $640 \mathrm{mCi} / \mathrm{m} \cdot \mathrm{mole} ; 10.0 \mu \mathrm{Ci} / \mathrm{ml}$.) at $37^{\circ} \mathrm{C}$ at specified times. The reaction was stopped by chilling on ice and the addition of $0.2 \mathrm{ml}$. of cold trichloroacetic acid $(17 \% \mathrm{w} / \mathrm{v})$ containing $2.5 \mathrm{mg}$ unlabeled thymidine/ml. After at least $30 \mathrm{~min}$ on ice, the precipitate in each tube was collected on membrane filters (Millipore HA, $\mathbf{0 . 4 5} \mu$ pore size) and washed with five $3 \cdot \mathrm{ml}$. washes of chilled water. The filters were dried and counted in a Tri-Carb scintillation spectrometer.

\section{(e) Determination of the type of DNA synthesized during infections}

Smith \& Levine (1965) described a method to differentiate the kind of DNA, phage or bacterial, synthesized at various times during the course of an infection. The large size difference between the phage and host DNA molecules allows separation of the high molecular weight host DNA from the smaller phage DNA by zone centrifugation through a sucrose gradient. Cells were infected with ${ }^{32} \mathrm{P}$-labeled phage, pulse-labeled with $\left[{ }^{3} \mathrm{H}\right]$ thymidine at various times, and then lysed. The ${ }^{32} \mathrm{P}$ is used as a marker for phage DNA and the tritium labels all newly synthesized DNA. The preparation of ${ }^{32}$-labeled phage, pulse-labeling of DNA synthesized during the course of infection with $\left[{ }^{3} \mathrm{H}\right]$ thymidine, the DNA extraction procedure, zone sedimentation on sucrose gradients and the assay of fractions from sucrose gradients were carried out as previously described (Smith \& Levine, 1965).

\section{(f) Detection of phage-carrying cells}

Phage-carrying cells are cells capable of producing phage. In such cells, intracellular phage genomes may be free or integrated as prophage. Cells to be tested were plated by the soft agar-overlay method with a background of galactose-negative cells on EMBgalactose agar plates. Plates were incubated for 48 to $60 \mathrm{hr}$ at room temperature. Phagecarrying cells gave rise to colonies with a surrounding halo of lysis due to spontaneous phage release, whereas cells not carrying phage produced no halo (Levine, 1957).

\section{Results}

(a) Mutants ts12.1 and ts18.1 carry mutations affecting early phage functions

Temperature-sensitive mutants can be used in temperature-shift experiments, from low to high temperature, to classify genes as playing a role early or late in phage formation. The purpose of this type of experiment is to test for the amount of phage production made possible by the gene product elaborated during the period of incubation at permissive temperature. For a gene product involved in the synthesis of phage DNA, a relatively short incubation at low temperature early in the latent period before the shift to high temperature should give some phage production. For a gene product needed late in the latent period for phage maturation, a more prolonged incubation at low temperature should be required.

Productive infections were initiated at $25^{\circ} \mathrm{C}$ in sensitive cells with multiplicities of $20 \mathrm{ts}$ mutants carrying the $c_{1}$ marker. After allowing time for adsorption and inactivation of free phage by antiserum, three portions were removed from each infection at intervals. One portion was plated to determine the extent of the latent period and the kinetics of appearance of free progeny particles at $25^{\circ} \mathrm{C}$. The second was immediately shaken with chloroform and assayed for intracellular phage. The third was shifted to $37^{\circ} \mathrm{C}$, incubated for an additional 120 minutes, then shaken with chloroform and assayed for progeny particles. 


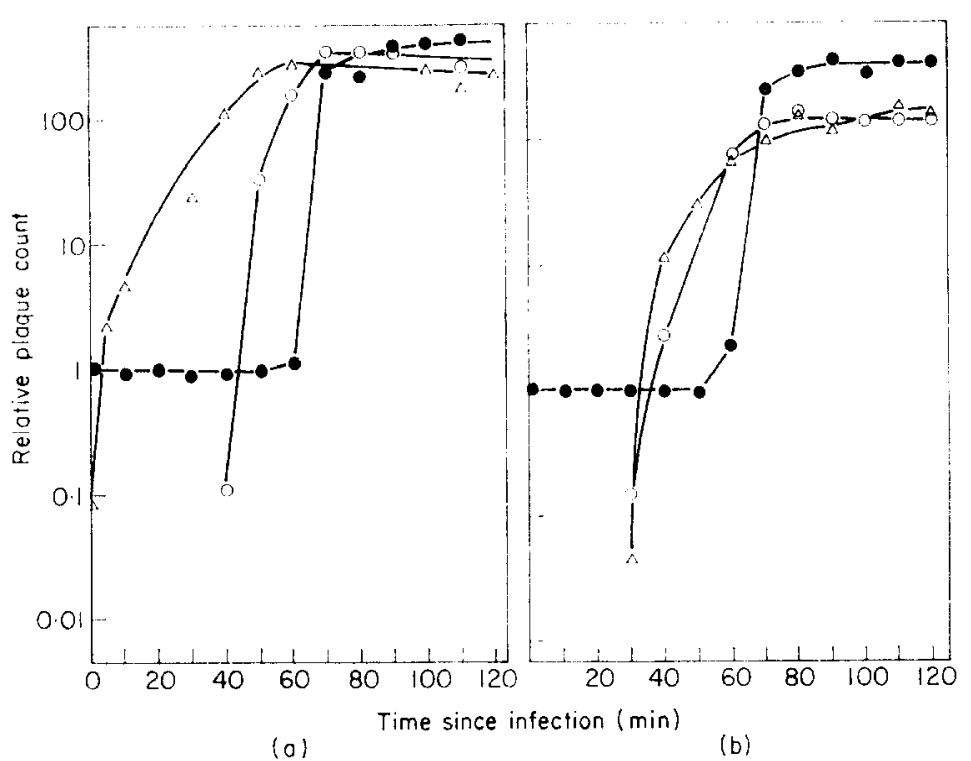

Fic. 1. Temperature-shift experiment. Infections were initiated at $25^{\circ} \mathrm{C}$ with a multiplicity of infection of $20 t s 12.1 c_{1}$ (a) and $20 t s 5.1 c_{1}$ (b). At intervals, 3 samples were removed from each infection. One was plated for a single-step growth curve (-O-O-), the second for intracellular phage (-O- $\mathrm{O}-$ ), and the third was shifted to $37^{\circ} \mathrm{C}$, incubated for an additional $120 \mathrm{~min}$ and assayed for progeny particles $(-\triangle-\triangle-)$.

Figure 1 presents the results of temperature-shift experiments with $t s 12.1 c_{1}$ and t.s5.1 $c_{1}$ mutants. The latent period at $25^{\circ} \mathrm{C}$ was about 60 minutes in both infections. Intracellular phage started to accumulate at about 40 minutes. A 5-minute incubation at $25^{\circ} \mathrm{C}$ of $t s 12.1 c_{1}$-infected cells followed by a shift to $37^{\circ} \mathrm{C}$ was sufficient to give a measurable phage yield (Fig. 1(a)). Near-normal yields were obtained when the infected cells were incubated for 30 minutes at the permissive temperature before the shift to $37^{\circ} \mathrm{C}$. In contrast, incubation of $t s 5.1 c_{1}$-infected cells for 30 minutes at $25^{\circ} \mathrm{C}$ before shifting to $37^{\circ} \mathrm{C}$ gave a final yield less than the input (Fig. $\mathrm{l}(\mathrm{b})$ ). Tem perature-shift data for $t s 18.1 c_{1}$-infected cells were similar to those shown for $t s 12.1 c_{1}$ in Figure 1(a). The data suggest that mutations 12.1 and 18.1 affect functions that act early in the latent period, and that mutation 5.1 affects a late function.

(b) Mutations 12.1 and 18.1 affect functions necessary for phage DNA synthesis

$\Lambda$ study was undertaken to compare the rates of DNA synthesis in uninfected cells and in cells infected with temperature-sensitive mutants. The rate of DNA synthesis was estimated by measuring the incorporation of $\left[{ }^{3} \mathrm{H}\right]$ thymidine into acid. insoluble material during one-minute pulses (Smith \& Levine, 1964). The rate in uninfected cells grown at $37^{\circ} \mathrm{C}$, showed a logarithmic increase with time which was proportional to the increase in cell number (Figs 2 and 3). Infection with $t s 5.1 c_{1}$ phage at a multiplicity of infection of 10 to 20 at the non-permissive temperature, $37^{\circ} \mathrm{C}$ (Fig. 2) resulted in an immediate depression of $\left[{ }^{3} \mathrm{H}\right]$ thymidine uptake. This was followed by a steep and sustained rise in the rate of DNA synthesis, reaching a peak at 25 to 30 minutes after infection, followed by a rapid fall. At about this time, cell lysis began. This pattern was almost identical to that reported by Smith \& Levine (1964) for a $c_{1}$ phage; that is, $t s 5.1 c_{1}$ induces a normal pattern of phage DNA synthesis at the non-permissive temperature. 


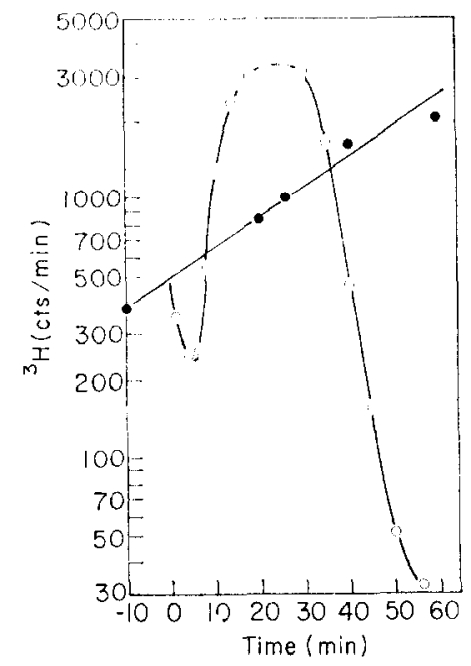

Fra. 2. The rate of incorporation of $\left[{ }^{3} \mathrm{H}\right]$ thymidine at $37^{\circ} \mathrm{C}$ into phage $t 85.1 c_{1}$.infected cells. - - - Uninfected control culture; - $\mathrm{O}-\mathrm{O}-$, infected cells.

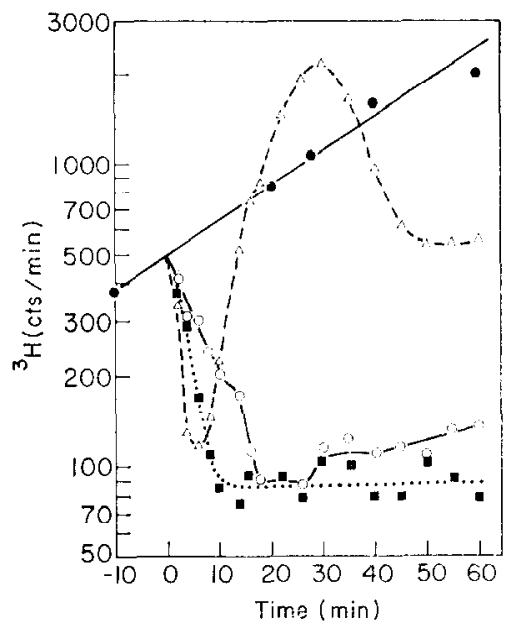

Fra. 3. The rate of incorporation of $\left[{ }^{3} \mathrm{H}\right]$ thymidine at $37^{\circ} \mathrm{C}$ into cells singly infected with phages ts $12.1 c_{1}$ and $t s 18.1 c_{1}$ and into mixedly infected cells. - - - Uninfected control cells;

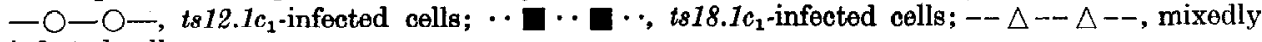
infected cells.

In contrast to $t s 5.1 c_{1}$ under non-permissive conditions both $t s 12.1 c_{1}$ and $t s 18.1 c_{1}$ failed to synthesize the large peak of phage DNA (Fig. 3). An immediate drop in the rate of DNA synthesis was observed in both infections. Following mixed infection with $t s 12.1 c_{1}$ and $t s 18.1 c_{1}$ (multiplicity of infection of 10 each), the pattern of rate of DNA synthesis was similar to that obtained with $t s 5.1 c_{1}$ or wild-type $c_{1}$. Therefore, complementation for phage DNA synthesis was achieved at high temperature. Further, the mixed infections gave near-normal phage yields consisting of both temperature-sensitive progeny particles. As might be expected, mixed infections between ts5.1 $c_{1}$ and $t s 12.1 c_{1}$ and $t s 5.1 c_{1}$ and $t s 18.1 c_{1}$ also gave normal patterns of rates of DNA synthesis (Fig. 4). The data are interpreted as demonstrating that we are dealing with two genes, gene 12 and gene 18, which control the formation of two different diffusible products, both 


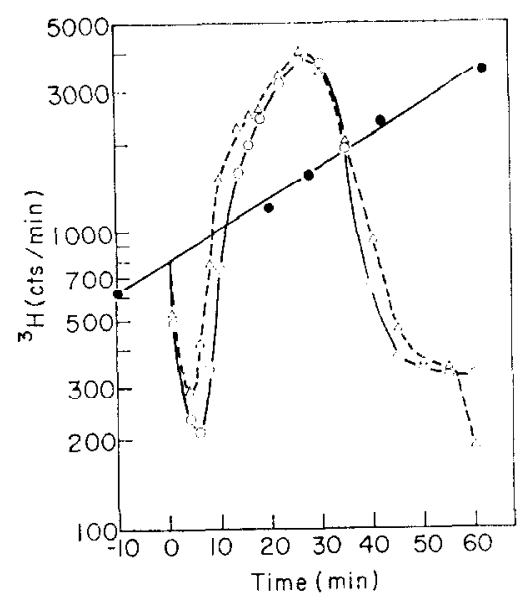

Frg. 4. The rate of incorporation of $\left[{ }^{3} \mathrm{H}\right]$ thymidine at $37^{\circ} \mathrm{C}$ in cells mixedly infected with $t 812.1 c_{1}$ plus $t 85.1 c_{1}(--\Delta--\Delta--)$, and $t s 18.1 c_{1}$ plus $t s 5.1 c_{1}(-\mathrm{O}-\mathrm{O}-) .---\odot-$, Uninfected control culture.

of which are necessary for the synthesis of phage P22 DNA. Bezdek \& Soska (1970) report similar findings with phage carrying the $t s 12.1$ mutation.

Smith \& Levine (1964) showed that wild-type $c^{+}$infections, under conditions leading to lysogeny, gave a pattern of DNA synthesis different from $c_{1}$ infections. There was an immediate depression of $\left[{ }^{3} \mathrm{H}\right]$ thymidine uptake, followed at 3 minutes by a steep rise in the rate, reaching a peak at 5 to 6 minutes. This peak was well above the control level of synthesis. At 6 minutes, the rate of DNA synthesis fell off rapidly, reaching a maximum inhibition of over $90 \%$ at 16 to 18 minutes. The rate of synthesis then increased until 40 to 45 minutes, when it began to equal that of uninfected cells. An examination of the type of DNA synthesized, by sucrose gradient analysis of DNA extracted from these complexes (Smith \& Levine, 1965), showed that the 6-minute peak consisted primarily of newly synthesized phage DNA. Bacterial DNA synthesis was progressively inhibited until 16 minutes, and then recovered. At this time phage DNA was no longer synthesized. More than $95 \%$ of the infected cells survived and gave rise to lysogenic progeny. Cells began to divide at control rates at about 40 minutes, correlating well with the observed resumption of DNA synthesis at normal rates at that time.

In cells infected at high temperature with multiplicities of $20 \mathrm{ts} 12.1 \mathrm{c}^{+}$or $20 \mathrm{ts} 18.1 \mathrm{c}^{+}$ phages, the rate of DNA synthesis decreased immediately and continued to decrease until a maximum inhibition occurred at about 16 minutes. The rate rapidly recovered after 16 minutes and equalled that of uninfected cells by about 40 minutes (Fig. 5). The early peak of DNA synthesis was not observed. This is the pattern of synthesis of host DNA in cells infected with wild-type $c^{+}$phage. Evidence that this pattern is due completely to effects on host DNA synthesis came from sucrose-gradient analysis of DNA extracted from the $t s 12.1 c^{+}$infection. Figure 6 shows two sucrose gradients of a more complete series from cells infected with ${ }^{32} \mathrm{P}$-labeled $t s 12.1 c^{+}$phage and pulse-labeled with $\left.{ }^{3} \mathrm{H}\right]$ thymidine for 2 minutes at the fourth and sixth minute of the infection. All the $\left[{ }^{3} \mathrm{H}\right]$ thymidine-labeled material banded in the position for host DNA. There was no evidence for synthesis of phage DNA in these sucrose gradients nor in any other sucrose gradients of DNA extracted at later times from this infection 


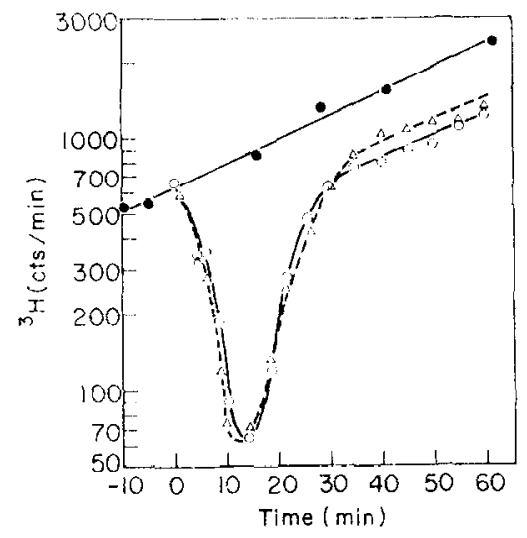

Fig. 5. The rate of incorporation of $\left[{ }^{3} \mathrm{H}\right]$ thymidine at $37^{\circ} \mathrm{C}$ into cells infected with $t s 12.1 \mathrm{c}^{+}$ $(-\Delta-\Delta--)$ and $t s 18.1 c^{+}(-\mathrm{O}-\mathrm{O}-) .---$ Uninfected control culture.

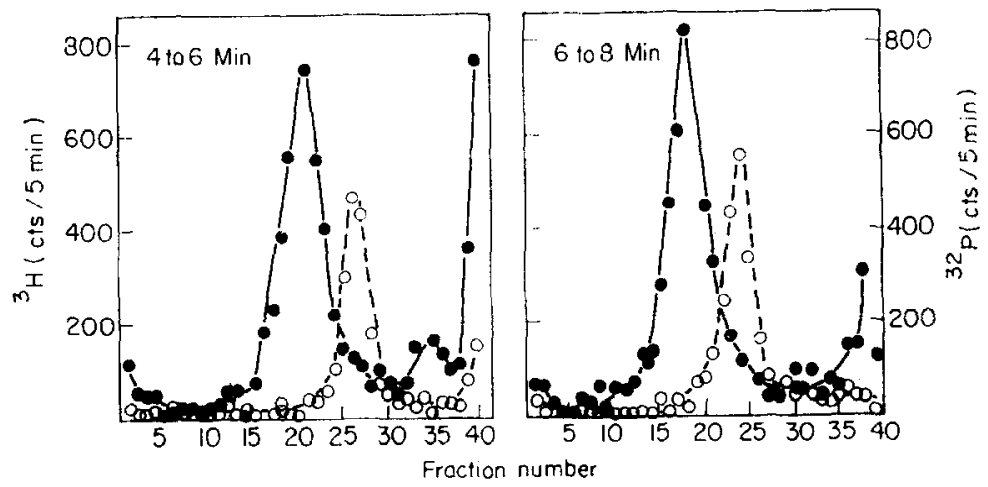

Fra. B. Separation of the kinds of DNA synthesized during the 4 to 6 and 6 to $8 \mathrm{~min}$ of an infection with $t 812.1 c^{+}$at $37^{\circ} \mathrm{C}$. $--\mathrm{O}_{--} \mathrm{O}_{--}$, Represents the ${ }^{32} \mathrm{P}$-labeled DNA introduced with the parental phage. - - - Represents the ${ }^{3} \mathrm{H}$-labeled DNA synthesized during the pulse treatments with $\left[{ }^{3} \mathrm{H}\right]$ thymidine. See Materials and Methods section for details.

at $37^{\circ} \mathrm{C}$. A sucrose gradient analysis of the $t s 18.1 c^{+}$infection has not been carried out, but it is assumed that the results would be similar. These data confirm the DNA. negative phenotype of the ts12.1 and $t s 18.1$ mutants.

Loveday \& Botstein (personal communication) have confirmed that these mutations affect phage DNA replication. They used $t s 12$ and $t s 18$ mutant phages grown in minimal medium containing deuterium oxide, ${ }^{15} \mathrm{NH}_{4} \mathrm{Cl}$ and $\left[{ }^{3} \mathrm{H}\right]$ thymidine to infect cells in light medium. Replication of the DNA was followed by assaying the density of the extracted labeled DNA in CsCl equilibrium density gradients. In both infections, replication (transfer of labeled DNA from fully heavy to hybrid density) was observed at permissive temperature but not at restrictive temperature. They concluded that the products of genes 18 and 12 must act for the phage DNA to be replicated even once.

Infections carried out at $25^{\circ} \mathrm{C}$ with $t s 12.1 c^{+}$and $t s 18.1 c^{+}$phages (multiplicity of infection $=22$ ) showed patterns of rates of DNA synthesis (Fig. 7) which are similar to that obtained with wild-type $c^{+}$. These infections resulted in an early peak of synthesis at about 16 minutes after infection, followed by a decrease until about 40 minutes, and finally recovery equal to the rate of DNA synthesis in uninfected cells. 


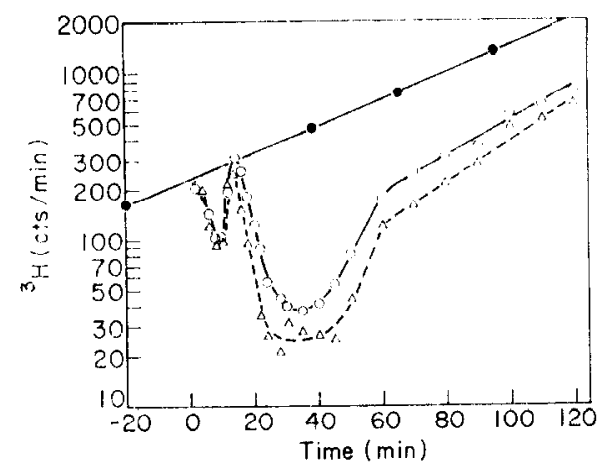

FIG. 7. The rate of incorporation of $\left[{ }^{3} \mathrm{H}\right]$ thymidine at $25^{\circ} \mathrm{C}$ into cells infected with $t 812.1 c^{+}$ $(--\Delta--\Delta--)$, and $t s 18.1 c^{+}(-\circlearrowleft-\circlearrowleft-) .-0-0-$, Uninfected control culture.

\section{(c) Mulations in gene 12 und gene 18 affect lysogenization}

More than $95 \%$ of the cells infected with $t s 12.1 c^{+}$or $t s 18.1 c^{+}$phages survived at high temperature. In contrast with the wild-type infection, however, these cells did not give rise to lysogenic progeny. This could be demonstrated by a study of the segregation pattern of infected cells. Log-phase cells were infected with a multiplicity of 20 phage particles at $37^{\circ} \mathrm{C}$. After a 5 -minute adsorption period, the cultures were diluted to $10^{3}$ cells $/ \mathrm{ml}$. in broth containing antiphage serum $(K=3)$. At intervals, samples were plated on EMB-galactose agar and incubated at $25^{\circ} \mathrm{C}$ for determination of the frequency of sensitive cells, phage-carrying cells, and total cells.

In the control infection at $37^{\circ} \mathrm{C}$ using wild-type $c^{+}$phage (Smith \& Levine, 1967), a high proportion of the cells (more than 95\%) survived as phage carriers (Fig. 8(u)). These began dividing after a lag of about one generation, and thereafter the total number of cells increased logarithmically. The proportion of phage carriers to total cells remained high for a few divisions, but eventually cells segregated as sensitives and lysogens. The ratio of phage carriers to total cells remained constant after the fifth generation. These data were interpreted in the following way: after an carly period of segregation of intracellular phage genomes, prophage integration had occurred because the capacity to produce phage was perpetuated in parallel with cell growth.

The temperature-sensitive mutants $t s 12.1 c^{+}$and $t s 18.1 c^{+}$(Fig. 8(b) and (c)) also gave a high proportion of cells surviving as phage carriers in the initial stages of the infection, but after some increase in cell titer, the absolute number of phage carriers remained constant. The ratio of phage carriers to total cells continued to decrease with each division, indicating the absence of stable lysogeny. This segregation pattern is similar to that described for int ${ }^{-}$phage mutants (Smith \& Levine, 1967) which cannot accomplish a late step necessary for prophage integration.

ts18 and ts12 mutants in mixed infections have been shown to complement for phage P22 DNA synthesis (Fig. 3). Paradoxically, this is not the case for lysogeny. Segregation experiments initiated at $37^{\circ} \mathrm{C}$ with mixed infections of $10 \mathrm{ts} 12.1 \mathrm{c}^{+}$and $10 t s 18.1 c^{+}$showed curves (Fig. 8(d)) similar to those described for each parent in single infection (Fig. 8(b) and (c)). That is, complementation for lysogeny does not occur. 'The question can be asked, does $t s 12.1 c^{+}$or $t s 18.1 c^{+}$interfere with lysogenization by $c^{+}$phage? It should be remembered that neither mutant affects normal 


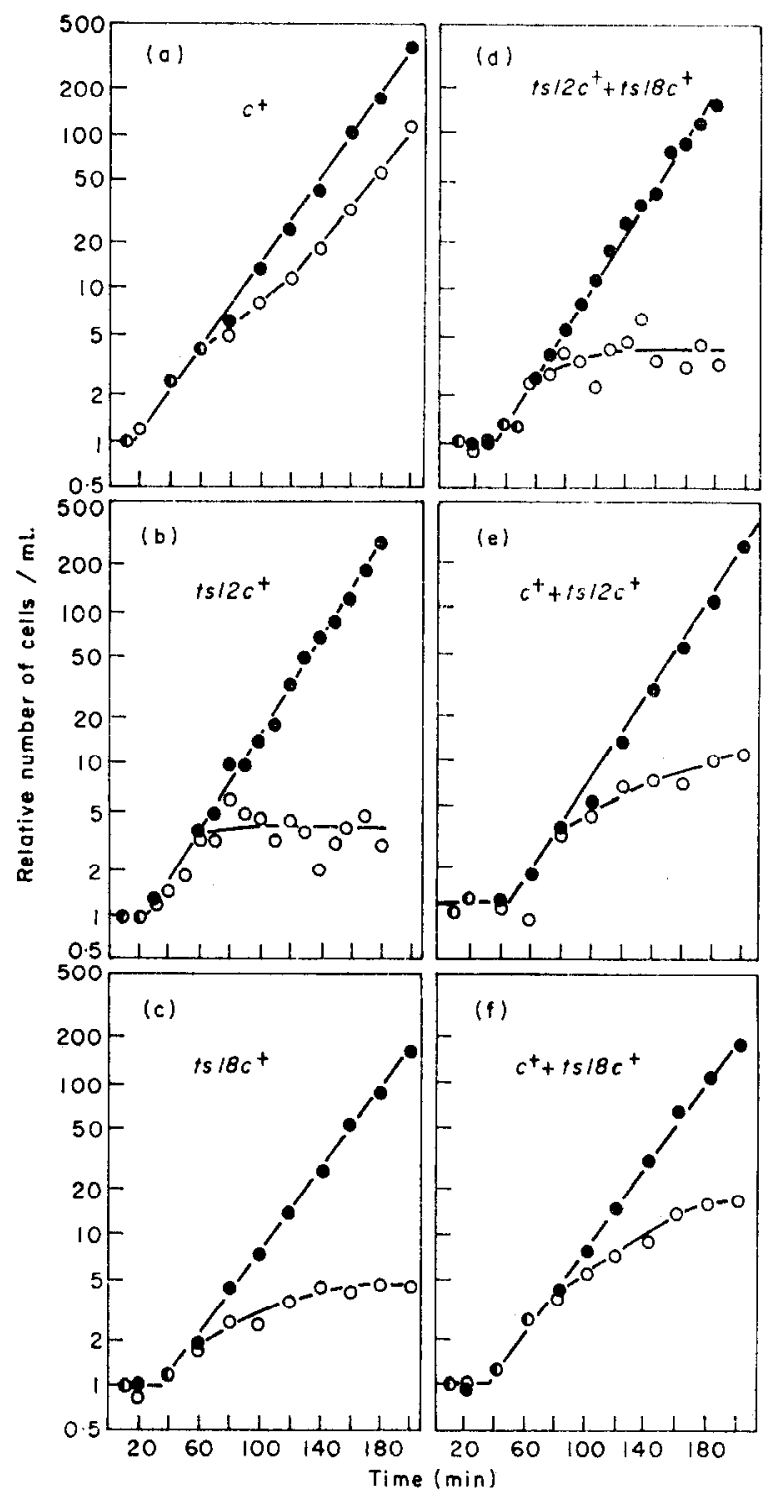

FIG. 8. Segregation of phage-carrying and sensitive cells at $37^{\circ} \mathrm{C}$ following infection with the indicated phages. Cell numbers are relative to the initial number of infected cells. - - Total number of cells; - $\mathrm{O}-\mathrm{O}-$, number of phage-carrying cells.

phage DNA synthesis in mixed infection with the wild-type phage (Fig. 4). To test this, segregation experiments were carried out at $37^{\circ} \mathrm{C}$ on mixed infections of 10 $t s 12.1 \mathrm{c}^{+}$with $10 \mathrm{c}^{+}$phages and also $10 t s 18.1 \mathrm{c}^{+}$with $10 \mathrm{c}^{+}$phages. The $t s 18.1 \mathrm{c}^{+}$ infections have given unequivocal results; stable lysogeny appears not to occur at $37^{\circ} \mathrm{C}$ (Fig. 8(f)). The $t s 12.1 c^{+}$infections have given variable results. In most experiments, the segregation curves indicate that the presence of the $t s 12$ mutation interferes with lysogeny and the segregation curves have been like those of $t s 12.1 c^{+}$alone (Fig. 8(e)). In a few experiments there was an indication of stable lysogeny. However, 
attempts to determine conditions which will consistently give lysogeny in this infection have not been successful.

In contrast with infection at high temperatures, cells infected at $25^{\circ} \mathrm{C}$ with $t s 12.1 c^{+}$ or $t s .18 .1 c^{+}$showed segregation patterns very similar to that of wild-type phage, giving high frequencies of stable integration. Once established at $25^{\circ} \mathrm{C}$, the lysogenic state is stable at high temperature. Revertants of $t s 12.1 \mathrm{c}^{+}$and $t s 18.1 \mathrm{c}^{+}$which form plaques at $37^{\circ} \mathrm{C}$ regained both the ability to synthesize phage DNA and to lysogenize at high temperature. These were not tested further to see if they were true revertants or second-site mutants.

\section{(d) Mapping of the 12 and 18 mutations}

The ts12.1 mutation is known to be closely linked to the $c$ region of the phage P22 genome. It maps 1.8 recombination units to the right of the $c$ region and 5.4 units to the left of the plaque-morphology marker, $h_{21}$ (Gough \& Levine, 1968). Two crosses were carried out between $t s 12.1$ and $t s 18.1$ phages which were reciprocal with respect to the alleles at the $c_{2}$ locus. Exponentially growing cells in M9-CAA medium were infected with mixtures of two phages (multiplicity of infection of 10 each) at $25^{\circ} \mathrm{C}$. After 10 minutes for adsorption, and 10 minutes for treatment with antiphage serum to inactivate unadsorbed phage, the bacteria were diluted and the incubation continued at $25^{\circ} \mathrm{C}$ until 180 minutes when the cells were lysed by addition of chloroform. Appropriate dilutions of progeny phage were then plated at 25 and at $37^{\circ} \mathrm{C}$. To determine the recombination frequencies between $t s$ loci, the number of plaque-forming units per $\mathrm{ml}$. at $37^{\circ} \mathrm{C}$ was doubled and divided by the plaque-forming units per ml. found at $25^{\circ} \mathrm{C}$. In addition, each plaque plating at $37^{\circ} \mathrm{C}$ was classified as to its clear or turbid morphology.

Mutations 12 and 18 are closely linked, showing $0.57 \%$ recombination. Of 313 non-temperature-sensitive recombinants of the cross $t s 12.1 c^{+} \times t s 18.1 c_{2}, 288$ were $c^{+}$and 25 were $c_{2}$, suggesting the gene order $c_{2}-t s 18-t s 12$ :

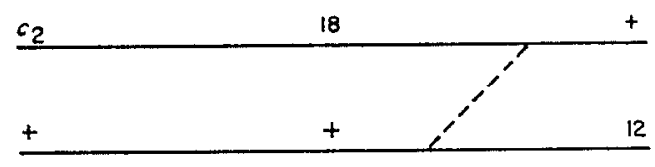

This order is confirmed by the results of the reciprocal cross, $t s 12.1 c_{2} \times t s 18.1 c^{+}$. In this case, 16 of the non-temperature-sensitive phage were $c^{+}$and 70 were $c_{2}$ :

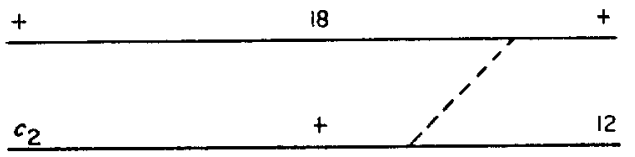

\section{Discussion}

The $t_{s} 12$ and $t s 18$ mutations ure pleiotropic. Infections at high temperature with either mutant show neither phage DNA synthesis nor lysogenization. Both effects are the consequence of a single mutational event, since revertants for both mutants simultaneously recover the capacity to replicate and to become prophage. Mixed infections with the two mutants, or either mutant and wild-type phage, results in 
normal synthesis of phage DNA and normal phage yields. The observed complementation suggests that each mutation represents a different gene and that the functional gene products of both loci are needed for the synthesis of phage DNA. In contrast, $t s 12.1 c^{+}$and $t s 18.1 c^{+}$phages do not complement for integration in mixed infection. Furthermore, each of these mutants interferes with lysogenization by wild type. This negative complementation for lysogeny raises the possibility that we are dealing with one locus and that the synthesis of phage DNA in mixed infection may be due to intragenic complementation. Despite this reservation, we will continue the discussion assuming that the $t s 12$ and $t s 18$ mutations represent two different but closely linked genes.

The data are consistent with the hypothesis that each of the two gene products has, in addition to its enzymic site, two additional sites, one specific for genome replication and the other for lysogeny; and further, that the active form of each product is multimeric. The multimer made at high temperature in a mutant-wild-type mixed infection, for instance, consists of both mutant and normal subunits. The enzymic and genome replication sites on the multimer are active, but the one for lysogeny is not; the mutant peptides interfere with lysogeny, causing the observed negative complementation. Mutants carrying chain-terminating mutations in either locus might not be expected to show negative complementation in mixed infection with wild-type phage of a non-permissive host, since in this case, no complete mutant peptides are synthesized. The multimer might then contain only normal peptides and complementation for both DNA synthesis and lysogeny would occur.

The inability of either mutant phage to lysogenize at $37^{\circ} \mathrm{C}$ is not, in itself, due to the failure to synthesize the early peak of phage DNA observed in wild-type infections, since mixed infections between the mutants and the mutants and wild-type, which complement for DNA synthesis, also fail to give rise to lysogens. This suggests that functional gene 18 and gene 12 products are required in a reaction (or reactions) for the establishment of lysogeny distinct from that in replication of the phage genome. The mutational lesions clearly affect events leading to integration of the prophage rather than maintenance of the lysogenie state. Lysogens carrying either $t s 12.1 \mathrm{c}^{+}$ or $18.1 \mathrm{c}^{+}$prophage are readily formcd at $25^{\circ} \mathrm{C}$. On shifting to $37^{\circ} \mathrm{C}$, these are as stable as wild-type lysogens.

The Campbell model (Campbell, 1962) proposes that integration of prophage is achieved by a recombinational event between circularized phage DNA and the host chromosome. The model appears to apply to the phage P22 system. Closed circular duplex molecules of input and of newly synthesized phage P22 DNA have been observed in infections leading to lysogeny (Rhoades \& Thomas, 1968). Two classes of mutations other than those in genes 18 and 12 are known to interfere with integration of prophage. (1) Mutants have been isolated which cannot grow on infection of recombination-deficient $\left(\mathrm{rec}^{-}\right)$host cells (Yamagami \& Yamamoto, 1970; Botstein \& Matz, 1970). These mutants, designated erf $^{-}$for essential recombination function, are defective for a phage-specified recombination system. Mixed infection of differently marked rrf $^{-}$mutants show greatly reduced recombination frequencies in $\mathrm{rec}^{-}$cells as compared to $\mathrm{rec}^{+}$host. Botstein \& Matz (1970) suggest that circularization of the infecting circularly permuted, terminally redundant phage DNA (Rhoades, MacHattie \& Thomas, 1968) by recombination in the terminally repetitious region of the molecules is the step essential for successful replication. Failure to circularize the phage DNA would be expected to interfere with lysogeny. This is the finding with erf ${ }^{-}$ 
mutants infecting $\mathrm{rec}^{-}$cells : no lysogenization is observed (Botstein \& Matz, 1970). However, erf ${ }^{-}$phage can become stable prophage in mixed infection of rec $^{-}$cells with $\mathrm{erf}^{+}$phage. Thus, the $\mathrm{erf}^{+}$function is required to establish, but not to maintain, lysogeny. (2) Smith \& Levine (1967) isolated mutants of phage P22, int mutants, which cannot accomplish a late step necessary for prophage integration. Under conditions which lead to high frequencies of lysogenization with wild-type phage, int mutant infections lead to host survival as non-lysogenic cells. The infecting phage genomes are progressively segregated among the progeny cells. int mutants can become prophage by complementation and these lysogens are stable. The int gene product is then also necessary for integration but not for maintenance of the lysogenic state. By analogy with the int mutants of phage $\lambda$ (Weil \& Signer, 1968; Echols, Gingery \& Moore, 1968; Signer, Weil \& Kimball, 1969; Echols, 1970), the int gene product of phage P22 is thought to govern the recombination between the circularized phage genome and the host chromosome. The pleiotropic action of the gene 18 and gene 12 products might be understood in the following way. Suppose genes 18 and 12 coded, respectively, for proteins with polymerase and ligase activities. Mutational lesions would be expected to interfere with phage genome replication. The same enzymic activities might be required to accomplish the covalent bonding needed to make closed circular phage DNA and/or to integrate the prophage. The same mutational lesions could then prevent establishment of prophage at one or the other step.

A replication complex for the vegetative synthesis of the DNA of phage P22 has been described (Botstein, 1968; Botstein \& Levine, 1968a,b; Levine, Chakravorty \& Bronson, 1970). This complex is an association of parental phage DNA, most of the newly synthesized phage DNA made during pulses with $\left[{ }^{3} \mathbf{H}\right]$ thymidine, and other cell constituents, and has a sedimentation rate in neutral sucrose gradients of over $1000 \mathrm{~s}$. The complex is one of the intermediates, intermediate $I$, in the synthesis and maturation of phage P22 DNA after infection or induction. Botstein \& Levine $(1968 a, b)$ reported that infecting mutant ts12.1 DNA molecules associate with intermediate $\mathrm{I}$ in the non-permissive condition. Infecting mutant $t 818.1 \mathrm{DNA}$ also associates with intermediate I at high temperature (unpublished results). The block to DNA synthesis which these mutants exhibit is due to failure to express gene 18 and gene 12 function in the replication machine rather than failure of template to associate with the machine itself.

The DNA-negative phenotype of the $t s 12$ and $t s 18$ mutants emphasizes a phage effect on host DNA metabolism which has been described previously (Smith \& Levine. 1965). Almost instantly on infection, host DNA synthesis is inhibited, and in the case of $c^{+}$infections, the inhibition is reversed at a very precise time, 15 to 16 minutes after infection. The phage exerts a number of controls on host DNA metabolism.

The mutations in genes 18 and 12 of phage P22 map close to one another just to the right of the $c$ region. They appear to be analogous to genes $O$ and $P$ of phage $\lambda$ in map position and in function in phage DNA replication. However, mutations in genes $O$ and $P$ do not interfere with lysogenization by phage $\lambda$ under conditions of infection similar to those used in this study (Brooks, 1965; Brown \& Arber, 1964: Signer, 1970) Freifelder, personal communication). 


\section{REFERENCES}

Bezdek, M. \& Soska, J. (1970). Molec. Gen. Genetics, 108, 243.

Butstein, D. (1968). J. Mol. Biol. 34, 621.

Botstein, D. \& Levine, M. (1968a). J. Mol. Biol. 34, 643.

Botstein, D. \& Levine, M. (1968b). Cold Spr. Harb. Symp. Quant. Biol. 33, 659.

Botstein, D. \& Matz, M. J. (1970). J. Mol. Biol. 54, 417.

Brooks, K. (1965). Virology, 26, 489.

Brown, A. \& Arber, W. (1964). Virology, 24, 237.

Campboll, A. (1962). Advanc. Genetics, 11, 101.

Echols, H. (1970). J. Mol. Biol. 47, 575.

Echols, H., Gingery, R. \& Moore, L. (1968). J. Mol. Biol. 34, 251.

Gough, M. \& Levine, M. (1968). Genetics, 58, 161.

Levine, M. (1957). Virology, 3, 22.

Levine, M., Chakravorty, M. \& Bronson, M. J. (1970). J. Virology, 6, 400.

Levine, M. \& Curtiss, R. (1961). Genetics, 46, 1573.

Rhoades, M., MacHattie, L. A. \& Thomas, C. A., Jr. (1968). J. Mol. Biol. $37,21$.

Rhoades, M. \& Thomas, C. A., Jr. (1968). J. Mol. Biol. 37, 41.

Signer, E. R. (1970). Virology, 40, 624.

Signer, E. R., Weil, J. \& Kimball, P. C. (1969). J. Mol. Biol. 46, 543.

Smith, H. O. \& Levine, M. (1964). Proc. Nat. Acad. Sci., Wash. 52, 356.

Smith, H. O. \& Levine, M. (1965). Virology, 25, 585.

Smith, H. O. \& Levine, M. (1967). Virology, 31, 207.

Weil, J. \& Signer, E. R. (1968). J. Mol. Biol. 34, 273.

Yamagami, H. \& Yamamoto, N. (1970). J. Mol. Biol. 53, 281. 